\title{
Article
}

\section{Solvent-Controlled Assembly of ionic Metal-Organic Frameworks Based on Indium and Tetracarboxylate Ligand: Topology Variety and Gas Sorption Properties}

Bing Zheng, Xiaodong Sun, Guanghua Li, Amy J Cairns, Victor

Kravtsov, Qisheng Huo, Yunling Liu, and Mohamed Eddaoudi

Cryst. Growth Des., Just Accepted Manuscript • DOI: 10.1021/acs.cgd.6b01031 • Publication Date (Web): 15 Jul 2016

Downloaded from http://pubs.acs.org on July 19, 2016

\section{Just Accepted}

"Just Accepted" manuscripts have been peer-reviewed and accepted for publication. They are posted online prior to technical editing, formatting for publication and author proofing. The American Chemical Society provides "Just Accepted" as a free service to the research community to expedite the dissemination of scientific material as soon as possible after acceptance. "Just Accepted" manuscripts appear in full in PDF format accompanied by an HTML abstract. "Just Accepted" manuscripts have been fully peer reviewed, but should not be considered the official version of record. They are accessible to all readers and citable by the Digital Object Identifier (DOI®). "Just Accepted" is an optional service offered to authors. Therefore, the "Just Accepted" Web site may not include all articles that will be published in the journal. After a manuscript is technically edited and formatted, it will be removed from the "Just Accepted" Web site and published as an ASAP article. Note that technical editing may introduce minor changes to the manuscript text and/or graphics which could affect content, and all legal disclaimers and ethical guidelines that apply to the journal pertain. ACS cannot be held responsible for errors or consequences arising from the use of information contained in these "Just Accepted" manuscripts. 


\title{
Solvent-Controlled Assembly of ionic Metal-Organic Frameworks Based on Indium and Tetracarboxylate Ligand: Topology Variety and Gas Sorption Properties
}

\author{
Bing Zheng, ${ }^{\text {ad }}$ Xiaodong Sun, ${ }^{\mathrm{a}}$ Guanghua Li, ${ }^{\mathrm{a}}$ Amy J. Cairns, ${ }^{\mathrm{b}}$ Victor Ch. Kravtsov, ${ }^{\mathrm{c}}$ \\ Qisheng Huo, ${ }^{\mathrm{a}}$ Y unling Liu, ${ }^{\mathrm{a}}$ and Mohamed Eddaoudi*b
}

a. State Key Laboratory of Inorganic Synthesis and Preparative Chemistry, College of Chemistry, Jilin University, Changchun 130012, P. R. China.

b. KAUST Advanced Membranes \& Porous Materials Center, 4700 King Abdullah University of Science and Technology, Thuwal 23955-6900, Kingdom of Saudi Arabia.

c. Institute of Applied Physics of Academy of Sciences of Moldova, Academy str. 5, MD 2028

Chisinau, Moldova.

d. Key Laboratory of Flexible Electronics (KLOFE) \& Institute of Advanced Materials (IAM), Jiangsu National Synergistic Innovation Center for Advanced Materials (SICAM), Nanjing Tech University (NanjingTech), 30 South Puzhu Road, Nanjing 211816, P. R. China

\footnotetext{
*To whom correspondence should be addressed.

Professor Yunling Liu

College of Chemistry

Jilin University

Changchun 130012, P. R. China

Fax: +86-431-85168624

E-mail: yunling@jlu.edu.cn
} 


\begin{abstract}
Four Metal-Organic Frameworks (MOFs) based on Indium and tetracarboxylate ligand have been synthesized through regulation of the solvent conditions, the resulted compounds not only exhibited rich structural topologies (pts, soc and unique topologies), but also interesting charge reversal framework features. By regulating the solvent, different building units (indium monomer, trimer) have been generated in situ, and they are connected with the ligand to form ionic frameworks 1-4, respectively. Among the synthesized four ionic frameworks, compounds $\mathbf{3}$ and $\mathbf{4}$ could keep their crystallinity upon heating temperature up to $300^{\circ} \mathrm{C}$ after fully removal of solvent guest molecules, they also exhibit the charge reversal framework features (3 adopts an overall cationic framework, while $\mathbf{4}$ has an anionic framework). Both compounds $\mathbf{3}$ and 4 exhibit significant uptake capacity for $\mathrm{CO}_{2}$ and $\mathrm{H}_{2}$, besides that, compounds 3 and 4 also present excellent selective adsorption of $\mathrm{CO}_{2}$ over $\mathrm{N}_{2}$ and $\mathrm{CH}_{4}$.
\end{abstract}




\section{Introduction}

Hydrogen storage and carbon dioxide capture have attracted lots of attention in recent years, since hydrogen is one of the most promising candidates for the replacement of current carbon-based energy source, and carbon dioxide is one of the main compounds of greenhouse gases, exploring high efficient adsorbents have been the keys. Various porous materials, ${ }^{1-3}$ such as activated carbon, microporous organic polymers and zeolites have been extensively studied as adsorbents for these two gases, the common shortages of these traditional materials are either low capacities or difficult regeneration processes. Metal-organic frameworks (MOF), as an emerging class of porous materials, have been known for their intriguing structural diversities of architecture ${ }^{4-7}$ and promising potential applications in large areas, ${ }^{8-19}$ especially in gas sorption and separation. ${ }^{20-29}$ In order to develop MOFs for $\mathrm{H}_{2}$ and $\mathrm{CO}_{2}$ sorption, people once tried to design and synthesis elongated ligands to obtain frameworks with large surface area. ${ }^{30-32}$ However, some research results show that large surface area is not necessarily advantageous for storing gas molecules in any conditions. ${ }^{33,34}$ According to the reported, the adsorption properties of $\mathrm{H}_{2}$ and $\mathrm{CO}_{2}$ in $\mathrm{MOF}$ are varied with pressures. Generally, gas capacities depend on surface areas and pore volumes of the MOFs at high pressures, while at low pressure, the capacities mainly depend on the heats of adsorption for gas molecules adsorbed in MOFs, therefore, increasing the interaction strength between gas molecules and MOFs can be helpful for adsorption properties of MOFs. 
As far as we know, there have been several strategies about enhancing interactions between gas molecules and MOFs, among these, the design of active sites on MOF structure has enjoyed great success, ${ }^{35-37}$ since at low pressure, both $\mathrm{H}_{2}$ and $\mathrm{CO}_{2}$ preferentially bind on the active sites that have large affinity. In addition, low-pressure gas adsorption can be also affected by catenation and interpenetration of framework. ${ }^{38-40}$ Recently, the charge-induced force in MOFs has been found have some influence for gas molecules and frameworks. However, the reported work are mainly anionic frameworks or introducing cations into MOFs by post-synthetic. ${ }^{41,42}$ Little research has been done on directly design and synthesis MOFs with charge reversal frameworks by using the same metal source and ligands, which should be contributed to the MOF structures mainly depends on the self-assemble of metal ions and organic ligands. Fortunately, solvent can also affect the conformation of frameworks.

In fact, solvent exhibits important roles for MOF synthesis, ${ }^{43-48}$ it not only can dissolve the reactants and promote the reaction work smoothly, but also act as template for conducting framework. Besides that, solvent has a large amount of species with different molecular polarity, which make it customary to screen a large number of solvents or solvent mixtures to find the best conditions for reactions. Since MOF is one kind of well-known crystalline material, solvent can not only greatly influence the mechanism of crystal growth but also incorporate into the crystalline lattice. If a solvent is in the pores or coordinated at the metal ion of the framework, the sorption properties would be also greatly affected not 
only by the structure of the MOF but also the chemical environment of the pore surface. Here, four indium-organic frameworks have been successfully obtained by simple changing the solvent under the similar synthetic conditions. By regulating the solvent, different building units (indium monomer, trimer) have been generated in situ, and they are connected with the ligand to form ionic frameworks with pts, soc and unprecedented topologies

\section{Experimental section}

\section{Materials and Methods.}

The ligand $\mathrm{H}_{4} \mathrm{EBDC}$ was prepared according to the literature. ${ }^{49}$ All the other reagents were obtained from commercial sources and used without further purification. Powder X-ray diffraction (XRD) data were collected on a Rigaku D/max-2550 diffractometer with $\mathrm{CuK} \alpha$ radiation $(\lambda=1.5418 \AA)$. The infrared (IR) spectra were recorded within the $4000-400 \mathrm{~cm}^{-1}$ region on a Nicolet Impact 410 FTIR spectrometer using $\mathrm{KBr}$ pellets. The peak intensities are described in each spectra as very strong (vs), strong (s), medium (m), weak (w), and broad (br). The elemental analyses were performed on a Perkin-Elmer 2400 element analyzer. The thermal gravimetric analyses (TG) were performed on NETZSCH STA 449C thermogravimetric analyzer used in air with a heating rate of $10^{\circ} \mathrm{C} \min ^{-1}$. Low pressure gas sorption measurements were performed on a fully automated micropore gas analyzer Autosorb-1C (Quantachrome Instruments) at relative pressure up to $1 \mathrm{~atm}$. The cryogenic temperatures were controlled using liquid nitrogen and liquid argon baths at temperatures of $77 \mathrm{~K}$ and 87 $\mathrm{K}$, respectively. 


\section{Preparation of Compound 1: $\left[\left(\mathrm{CH}_{3}\right)_{2} \mathrm{NH}_{2}\right][\mathrm{In}(\mathrm{EBDC})] \cdot 2 \mathrm{DMF} \cdot 2 \mathrm{DMSO} \cdot \mathrm{H}_{2} \mathrm{O}$} 5,5'-(1,2-ethynediyl)bis(1,3-benzenedicarboxylic acid) $\left(\mathrm{H}_{4} \mathrm{EBDC}\right)(10.0 \mathrm{mg}, 0.0285$ $\mathrm{mmol}), \mathrm{In}\left(\mathrm{NO}_{3}\right)_{3} \cdot 5 \mathrm{H}_{2} \mathrm{O}(40.0 \mathrm{mg}, 0.102 \mathrm{mmol}), \mathrm{DMF}(1.0 \mathrm{~mL})$, DMSO $(1.0 \mathrm{~mL})$, and $\mathrm{HNO}_{3}(0.10 \mathrm{~mL}, 2.7 \mathrm{M}$ in DMF) were added to a vial, and the solution was heated to $85{ }^{\circ} \mathrm{C}$ for $36 \mathrm{~h}$. Colorless polyhedral crystals were collected and air-dried (17.6 mg, 74\% yield based on $\left.\mathrm{H}_{4} E B D C\right)$. Elemental analysis calcd (\%) for $1, \mathrm{C}_{30} \mathrm{H}_{42} \mathrm{~N}_{3} \mathrm{~S}_{2} \mathrm{O}_{13}$ In : C 43.33, H 5.09, N 5.05, S 7.71; found: C 42.83, H 4.78, N 4.72, S 7.54.

IR spectrum (KBr, cm $\left.{ }^{-1}\right)$ : 3059(br), 2927(w), 2774(br), 2453(br), 1662(s), 1594(s), 1547(s), 1439(s), 1377(s), 1307(s), 1144(m), 1113(m), 1029(m), 939(s), 831(s), 783(s), 745(s), 603(w), 551(w), 480(m).

\section{Preparation of compound 2: $\left[\left(\mathrm{CH}_{3}\right)_{2} \mathrm{NH}_{2}\right][\mathrm{In}(\mathrm{EBDC})] \cdot \mathrm{DMF}$}

$\mathrm{H}_{4} \mathrm{EBDC}(5.0 \mathrm{mg}, 0.0143 \mathrm{mmol}), \mathrm{In}\left(\mathrm{NO}_{3}\right)_{3} \cdot 5 \mathrm{H}_{2} \mathrm{O}(10.0 \mathrm{mg}, 0.025 \mathrm{mmol})$, DMF (1 $\mathrm{mL})$, and $\mathrm{HNO}_{3}(0.2 \mathrm{~mL}, 2.7 \mathrm{M}$ in DMF) were added to a vial, and the solution was heated to $85^{\circ} \mathrm{C}$ for $36 \mathrm{~h}$. Colorless cubic crystals were collected and air-dried (11.5 mg, $69 \%$ yield based on $\mathrm{H}_{4} \mathrm{EBDC}$ )

Elemental analysis calcd (\%) for 2, $\mathrm{C}_{23} \mathrm{H}_{21} \mathrm{~N}_{2} \mathrm{O}_{9}$ In : C 47.28, H 3.62, N 4.79; found: C 48.09, H 3.76, N 4.62.

IR spectrum $\left(\mathrm{KBr}, \mathrm{cm}^{-1}\right)$ : 3072(br), 2774(br), 2431(br), 1639(s), 1578(s), 1433(s), 1388(s), 1296(s), 1273(m), 1190(w), 1106(w), 1013(m), 923(w), 824(w), 770(s), 725(m), 725(w), 664(w), 490(w).

Preparation of compound $\quad$ 3: $\quad\left[\operatorname{In}_{3} \mathrm{O}(\mathrm{EBDC})_{1.5}\left(\mathrm{H}_{2} \mathrm{O}\right)_{3}\right]$ 
$\left[\mathrm{NO}_{3}\right] \cdot 2 \mathrm{DMF} \cdot 2\left(\mathrm{CH}_{3} \mathrm{CN}\right) \cdot 0.75\left(\mathrm{H}_{2} \mathrm{O}\right)$

$\mathrm{H}_{4} \mathrm{EBDC}(10.0 \mathrm{mg}, 0.0285 \mathrm{mmol}), \mathrm{In}\left(\mathrm{NO}_{3}\right)_{3} \cdot 5 \mathrm{H}_{2} \mathrm{O}(40.0 \mathrm{mg}, 0.102 \mathrm{mmol}), \mathrm{DMF}(1.0$ $\mathrm{mL}), \mathrm{CH}_{3} \mathrm{CN}(1.0 \mathrm{~mL})$, and $\mathrm{HNO}_{3}(0.20 \mathrm{~mL}, 2.7 \mathrm{M}$ in DMA) were added to a vial, and the solution was heated to $85^{\circ} \mathrm{C}$ for $36 \mathrm{~h}$. Colorless polyhedral crystals were collected and air-dried (25.2 mg, 67\% yield based on $\mathrm{H}_{4}$ EBDC).

Elemental analysis calcd (\%) for 3, $\mathrm{C}_{40} \mathrm{H}_{43.5} \mathrm{~N}_{6} \mathrm{O}_{22.75} \mathrm{In}_{3}$ : C 36.49, H 3.33, N 6.38; found: C 35.61, H 3.45, N 6.72.

IR spectrum $\left(\mathrm{KBr}, \mathrm{cm}^{-1}\right)$ : 3415(br), 3072(w), 2927(w), 2465(br), 1642(s), 1586(s), 1433(s), 1366(s), 1092(m), 1009(m), 920(m), 783(s), 725(s), 633(s), 551(m), 501(m), 436(m).

Preparation $\quad$ of $\quad$ compound $\quad 4$ : $\left[\left(\mathrm{CH}_{3}\right)_{2} \mathrm{NH}_{2}\right]\left[\operatorname{In}_{3} \mathrm{O}(\mathrm{EBDC})_{1.5}\left(\mathrm{H}_{2} \mathrm{O}\right)_{3}\right]_{2}[\operatorname{In}(\mathrm{EBDC})]_{3} \cdot 8 \mathrm{DMF} \cdot 13\left(\mathrm{CH}_{3} \mathrm{CN}\right) \cdot 10\left(\mathrm{H}_{2} \mathrm{O}\right)$

$\mathrm{H}_{4} \mathrm{EBDC}(10.0 \mathrm{mg}, 0.0285 \mathrm{mmol}), \mathrm{In}\left(\mathrm{NO}_{3}\right)_{3} \cdot 5 \mathrm{H}_{2} \mathrm{O}(40.0 \mathrm{mg}, 0.102 \mathrm{mmol})$, DMA (1.0 mL), $\mathrm{CH}_{3} \mathrm{CN}(1.0 \mathrm{~mL})$, and $\mathrm{HNO}_{3}(0.10 \mathrm{~mL}, 2.7 \mathrm{M}$ in DMA) were added to a vial, and the solution was heated to $85^{\circ} \mathrm{C}$ for $36 \mathrm{~h}$. Colorless trigonal crystals were collected and air-dried (15.8mg, $71 \%$ yield based on $\left.\mathrm{H}_{4} \mathrm{EBDC}\right)$.

Elemental analysis calcd (\%) for 4, $\mathrm{C}_{168} \mathrm{H}_{187} \mathrm{~N}_{22} \mathrm{O}_{74} \mathrm{In}_{9}$ : C 42.64, H 3.98, N 6.51; found: C 40.59, H 3.48, N 6.32 .

IR spectrum $\left(\mathrm{KBr}, \mathrm{cm}^{-1}\right)$ : 3384br, 3207br, 3072w, 2934w, 2774w, 2431w, 1639s, 1578s, 1433s, 1388s, 1296s, 1273m, 1190w, 1106w, 1013m, 923w, 824m, 770s, 725s, 673w, 634m, 612br, 551w, 490m, 436m.

The as-synthesized compounds $\mathbf{1 - 4}$ were insoluble in water and common organic 
solvents. The phase purity of as-synthesized samples was confirmed by the evident similarities between the calculated and the experimental X-ray powder diffraction patterns (see Supporting Information Figure S1).

\section{X-ray structure determinations.}

Suitable single-crystals of 1-4 were selected for single-crystal X-ray diffraction analyses. The intensity data were collected on a Bruker Smart CCD diffractometer for 1-3 and a Bruker SMART Apex 2 diffractometer for 4 by using graphite-monochromated Mo-K $\alpha$ radiation $(\lambda=0.71073 \AA)$. Data processing was accomplished with the SAINT processing program and the structures were solved by direct methods, and all non-hydrogen atoms were subjected to anisotropic refinement by full-matrix least-squares on $\mathrm{F}^{2}$ by using the SHELXTL program. The solvent molecules in compounds $\mathbf{1 , 2}$ and $\mathbf{4}$ are highly disordered, and attempts to locate and refine the solvent peaks were not reasonable. SQUEEZE subroutine of the PLATON software suit was used to remove the scattering from the highly disordered guest molecules. The resulting new files were used to further refine the structures.

The guest molecular formulas of 1- $\mathbf{4}$ are ascertained from elemental analysis, thermogravimetric analysis, and IR spectroscopy, the formulas are suggested to be $\left[\left(\mathrm{CH}_{3}\right)_{2} \mathrm{NH}_{2}\right][\mathrm{In}(\mathrm{EBDC})] \cdot 2 \mathrm{DMF} \cdot 2 \mathrm{DMSO} \cdot \mathrm{H}_{2} \mathrm{O}$ for $\mathbf{1},\left[\left(\mathrm{CH}_{3}\right)_{2} \mathrm{NH}_{2}\right][\operatorname{In}(\mathrm{EBDC})] \cdot 2 \mathrm{DMF}$ for 2, $\quad\left[\operatorname{In}_{3} \mathrm{O}(\mathrm{EBDC})_{1.5}\left(\mathrm{H}_{2} \mathrm{O}\right)_{3}\right] \quad\left[\mathrm{NO}_{3}\right] \cdot 2 \mathrm{DMF} \cdot 2\left(\mathrm{CH}_{3} \mathrm{CN}\right) \cdot 0.75\left(\mathrm{H}_{2} \mathrm{O}\right)$ for $\mathbf{3}$, and $\left[\left(\mathrm{CH}_{3}\right)_{2} \mathrm{NH}_{2}\right]\left[\operatorname{In}_{3} \mathrm{O}(\mathrm{EBDC})_{1.5}\left(\mathrm{H}_{2} \mathrm{O}\right)_{3}\right]_{2}[\operatorname{In}(\mathrm{EBDC})]_{3} \cdot 8 \mathrm{DMF} \cdot 13\left(\mathrm{CH}_{3} \mathrm{CN}\right) \cdot 10\left(\mathrm{H}_{2} \mathrm{O}\right)$ for 4. The CCDC-860713-860716 containing the supplementary crystallographic data for this manuscript can be obtained free of charge from the Cambridge Crystallographic 
Data Centre via www.ccdc.cam.ac.uk/data_request/cif. Additional details are presented in Table 1.

\section{Results and discussion}

Here, a solvent-controlled synthesis of crystalline MOFs has been described (Scheme 1), indium nitride and a tetracarboxylate ligand have been chosen as the metal node and linker, respectively. By regulation of the solvent conditions, four MOFs with different structures have been constructed, the resulted compounds are anionic or cationic frameworks, and exhibiting pts, soc and unprecedented topologies. The structures of the frameworks have been characterized in details, together with their gas sorption and separation properties.

Crystal Structure of 1. As shown in Fig.1, reaction between 5,5'-(1,2-ethynediyl)bis(1,3-benzenedicarboxylic acid) $\quad\left(\mathrm{H}_{4}\right.$ EBDC $) \quad$ and $\mathrm{In}\left(\mathrm{NO}_{3}\right)_{3} \cdot 5 \mathrm{H}_{2} \mathrm{O}$ in a $\mathrm{N}, \mathrm{N}$-dimethylformamide (DMF)/Dimethylsulfoxide (DMSO) solution in the presence of $\mathrm{HNO}_{3}$ yields a homogeneous microcrystalline material, characterized and formulated by elemental analysis and single-crystal X-ray diffraction $(\mathrm{SCD}) \quad$ studies as $\left[\left(\mathrm{CH}_{3}\right)_{2} \mathrm{NH}_{2}\right][\mathrm{In}(\mathrm{EBDC})] \cdot 2 \mathrm{DMF} \cdot 2 \mathrm{DMSO} \cdot \mathrm{H}_{2} \mathrm{O}$ (Compound 1). In the crystal structure of $\mathbf{1}$, each $\mathrm{In}^{3+}$ centre is eight-coordinated to oxygen atoms of four carboxylate groups from four EBDC ${ }^{4-}$ ligands. Each ligands binds to four separate $\operatorname{In}^{3+}$ centres. Accordingly, the inorganic $\left(\left[\operatorname{In}\left(\mathrm{O}_{2} \mathrm{C}\right)_{4}\right]^{-}\right)$and organic $\left(\mathrm{EBDC}^{4-}\right) \mathrm{MBBs}$ (molecular-building-block) can be rationalized as having tetrahedral and square-planar geometry, respectively (Fig 1a). The anionic framework 
in $\mathbf{1}$ has pts topology and contains two types of intersecting channels along the $c$ and $b$ axis, with an approximate diameter of $6.655 \times 5.567 \AA$ and $5.567 \times 5.567 \AA$ (point-to-point and including van der Waals radii, Fig. $1 \mathrm{~b}$ and 1c). Since both the inorganic $\left(\left[\operatorname{In}\left(\mathrm{O}_{2} \mathrm{C}\right)_{4}\right]^{-}\right)$and organic $\left(\mathrm{EBDC}^{4-}\right)$ MBBs can be simplified into 4-connected node, the resulting structure of $\mathbf{1}$ is a $(4,4)$-connected pts network (Figure 1d) with $\left[4^{2} .8^{4}\right]$ tile (Figure 1e). It is worth noting that the charge is balanced by $\left[\left(\mathrm{CH}_{3}\right)_{2} \mathrm{NH}_{2}\right]^{+}$counter ions, which are from the decomposition of the DMF solvent.

Crystal Structure of 2. Similarly reaction of $\mathrm{In}\left(\mathrm{NO}_{3}\right)_{3} \cdot 5 \mathrm{H}_{2} \mathrm{O}$ and $\mathrm{H}_{4} \mathrm{EBDC}$ but only using DMF as solvent, permitted the construction of the unprecedented, novel MOF, formulated by elemental analysis and $\mathrm{SCD}$ analysis as $\left[\left(\mathrm{CH}_{3}\right)_{2} \mathrm{NH}_{2}\right][\mathrm{In}(\mathrm{EBDC})] \cdot \mathrm{DMF}$ (Compound 2). The 3-periodic anionic MOF consists of two crystallographically independent $\mathrm{In}^{3+}$ atoms and two $\mathrm{EBDC}^{4-}$ units. Each $\mathrm{In}^{3+}$ atom is coordinated by four bidentate chelating carboxylate groups from four $\mathrm{EBDC}^{4-}$ ligands to form a tetrahedral node. Each ligand binds to four separate $\operatorname{In}^{3+}$ centres to form a square-planar node. The assembly of these two types of nodes generates a distinctive 3D framework (Fig 2a and table S1), which is the first report so far to the best of our knowledge. Compound 2 contains two types of channels, i.e. rectangular and triangular in shape and measure approximately of $6.366 \times 4.420 \AA$ and $5.174 \times 5.174 \AA$, respectively (point-to-point and including van der Waals radii, Fig. $2 \mathrm{~b}$ and $2 \mathrm{c}$ ). The simplified two 4-connected nodes alternately connected to form a new topology (Fig.2d) and with unique tile shown in Fig. 2e.

Crystal Structure of 3. Similar reaction conditions as for 2 in the presence of $1 \mathrm{~mL}$ 
$\mathrm{CH}_{3} \mathrm{CN}$ and $0.2 \mathrm{~mL} \mathrm{HNO}_{3}$ in DMA (2.7M) give polyhedral crystals formulated as $\left[\mathrm{In}_{3} \mathrm{O}(\mathrm{EBDC})_{1.5}\left(\mathrm{H}_{2} \mathrm{O}\right)_{3}\right] \quad\left[\mathrm{NO}_{3}\right] \cdot 2 \mathrm{DMF} \cdot 2\left(\mathrm{CH}_{3} \mathrm{CN}\right) \cdot 0.75\left(\mathrm{H}_{2} \mathrm{O}\right)$ (Compound 3). The crystallographic analysis of $\mathbf{3}$ revealed that it crystallizes in the cubic space group Pm-3n and its structure contains indium trimer building blocks, $\left[\operatorname{In}_{3} \mathrm{O}\left(\mathrm{O}_{2} \mathrm{C}\right)_{6}\left(\mathrm{H}_{2} \mathrm{O}\right)_{3}\right]^{+}$, whereby each indium cation adopts an octahedral $\left[\operatorname{InO}_{5}\left(\mathrm{H}_{2} \mathrm{O}\right)\right]$ coordination environment. Each trimer unit is linked by six separate organic linkers to produce a novel 3D structure. The indium trimeric building units can be rationalized as a 6-connected trigonal prismatic building unit and can be regarded as a pseudo-octahedron. The organic $\mathrm{H}_{4} \mathrm{EBDC}$ linker can be simplified as 4-connected rectangular-planar node. Accordingly, the assembly of such 4- and 6-connected nodes results in the formation of an edge-transitive 3-periodic network with soc topology (Fig 3a). To date, only two examples of trimeric building unit based MOFs with soc topology have been reported. ${ }^{50}$ The overall framework of compound $\mathbf{3}$ is cationic and the charge balance is provided by disordered $\left[\mathrm{NO}_{3}\right]^{-}$anions. Compound $\mathbf{3}$ exhibits an interesting pore system because it contains two well-defined types of infinite channels, namely an intersecting hydrophobic and hydrophilic channel system. The relative span of the cage is estimated to be $14.96 \AA$, while the channels measure approximately $7.66 \AA \AA$ (point-to-point and including van der Waals radii, Fig. 3b). The simplified 4- and 6-connected nodes alternately connected to form (4. 6)-connected network (Fig.3c), with two distinct tiles: $\left[4^{4} \cdot 6^{2}\right]$ and $\left[4^{6} \cdot 8^{9}\right]$ (Fig. 3d).

Crystal Structure of 4. Under similar reaction conditions for $\mathbf{3}$, just changing the DMF solvent to DMA, led to the formation of a novel MOF with the formula 
$\left[\left(\mathrm{CH}_{3}\right)_{2} \mathrm{NH}_{2}\right]\left[\mathrm{In}_{3} \mathrm{O}(\mathrm{EBDC})_{1.5}\left(\mathrm{H}_{2} \mathrm{O}\right)_{3}\right]_{2}[\mathrm{In}(\mathrm{EBDC})]_{3} \cdot 8 \mathrm{DMF} \cdot 13\left(\mathrm{CH}_{3} \mathrm{CN}\right) \cdot 10\left(\mathrm{H}_{2} \mathrm{O}\right)$

(Compound 4). Compound 4 crystallizes in the chiral space group R32, and contains two distinctly different $\mathrm{In}^{3+}$ configurations: the monomeric $\left[\operatorname{In}\left(\mathrm{O}_{2} \mathrm{C}\right)_{4}\right]^{-}$site and the trimeric $\left[\mathrm{In}_{3} \mathrm{O}\left(\mathrm{O}_{2} \mathrm{C}\right)_{6}\left(\mathrm{H}_{2} \mathrm{O}\right)_{3}\right]^{+}$clusters. Each $\mathrm{H}_{4}$ EBDC ligand is linked by two monomeric $\mathrm{In}^{3+}$ centres and two trimeric building units in a cis configuration to generate a novel 3D anionic network (Fig 4a). Compound 4 contains three types of channels, the space-filling representations of the framework showing the channels along [100], [110] and [111] directions, respectively (Fig. 4b, c, d). If the monomeric $\left[\operatorname{In}\left(\mathrm{O}_{2} \mathrm{C}\right)_{4}\right]^{-}$building unit is simplified as 4-connected tetrahedral node, the trimer as 6-connected node, and the $\mathrm{H}_{4} \mathrm{EBDC}$ ligand served as 4-connected square node, the $3 \mathrm{D}$ framework of 4 can be simplified as a rare, ternary $(4,4,6)$-connected net (Fig.4e) with four distinct tiles: $\left[6^{3}\right],\left[6^{4}\right],\left[6^{6}\right]$ and $\left[4^{6} .6^{8}\right]$ (Fig. 4f). To the best of our knowledge, only one example of In-MOF contains both indium monomer and trimer units have been reported..$^{51}$

If we kept the monomer $\left[\operatorname{In}\left(\mathrm{O}_{2} \mathrm{C}\right)_{4}\right]^{-}$and trimer $\left[\operatorname{In}_{3} \mathrm{O}\left(\mathrm{O}_{2} \mathrm{C}\right)_{6}\left(\mathrm{H}_{2} \mathrm{O}\right)_{3}\right]^{+}$as still 4 or 6 connected nodes, while the tetracarboxylate ligand is simplified as two 3-c branch points, which is according to the latest topological analysis method, ${ }^{52}$ the topologies of compounds 1-4 would be totally different (see Fig S5-8), the 3D frameworks of 1-2 can be simplified as $(3,4)$-connected net with Schälfli symbol of $\left\{6^{2} \cdot 8^{4}\right\}\left\{6^{2} \cdot 8\right\}_{2}$ and $\left\{6 \cdot 8^{2}\right\}_{2}\left\{6 \cdot 8^{5}\right\}\left\{6^{2} \cdot 8^{4}\right\}\left\{6^{2} \cdot 8\right\}_{2}$, respectively, while compound 3 can be simplified as $(3,6)$-connected net with Schälfli symbol of $\left\{5^{3}\right\}_{3}\left\{5^{6} \cdot 8^{6} \cdot 9^{3}\right\}$, and compound 4 is $(3,4,6)$-connected net with Schälfli symbol of $\left\{6 \cdot 7^{2}\right\}_{12}\left\{6^{3} \cdot 7^{12}\right\}_{2}\left\{7^{5} \cdot 8\right\}_{3}$. The 
calculated result by TOPOS for the linker simplified as 3 or 4 connected node have been illustrated in table S2.

\section{Thermogravimetric Analysis.}

The thermal stability of compounds $\mathbf{1 - 4}$ have been evaluated in the temperature range of $35-700^{\circ} \mathrm{C}$ under an air atmosphere (Supporting Information Figure S3). Thermogravimetric analysis for compound 1 shows a weight loss of $43.84 \%$ (calcd: $44.08 \%$ ) between 35 and $300^{\circ} \mathrm{C}$ which corresponding to the loss of $\mathrm{C}_{3} \mathrm{H}_{7} \mathrm{ON}, \mathrm{H}_{2} \mathrm{O}$, $\mathrm{C}_{2} \mathrm{H}_{6} \mathrm{SO}$ and $\left(\mathrm{CH}_{3}\right)_{2} \mathrm{NH}_{2}$ guest in the cavity. the further weight loss of $39.50 \%$ between 300 and $500{ }^{\circ} \mathrm{C}$ should be attributed to the release of organic $\mathrm{H}_{4} \mathrm{EBDC}$ ligands (calcd: 39.23\%). XRD studies indicated that the final product, upon calcinations above $500^{\circ} \mathrm{C}$, is a main phase of $\mathrm{In}_{2} \mathrm{O}_{3}$ (JCPDS: 65-3170).

Thermogravimetric analysis for compound 2 shows a weight loss of $20.55 \%$ (calcd: $20.40 \%$ ) between 35 and $160^{\circ} \mathrm{C}$ which corresponding to the loss of $\mathrm{C}_{3} \mathrm{H}_{7} \mathrm{ON}$ and $\left(\mathrm{CH}_{3}\right)_{2} \mathrm{NH}_{2}$ guest in the cavity. On further heating, a two-step weight loss of $55.57 \%$ between 160 and $500{ }^{\circ} \mathrm{C}$ should be attributed to the release of organic $\mathrm{H}_{4} \mathrm{EBDC}$ ligands (calcd: 55.84\%). XRD studies indicated that the final product, upon calcinations above $500^{\circ} \mathrm{C}$, is a main phase of $\operatorname{In}_{2} \mathrm{O}_{3}$ (JCPDS: 65-3170).

For compound 3, Thermogravimetric analysis shows a weight loss of $32.98 \%$ (calcd: $32.73 \%$ ) between 35 and $380^{\circ} \mathrm{C}$, which corresponding to the loss of $\mathrm{C}_{3} \mathrm{H}_{7} \mathrm{ON}, \mathrm{CH}_{3} \mathrm{CN}$, $\mathrm{H}_{2} \mathrm{O}$, and $\mathrm{NO}_{3}{ }^{-}$guest in the cavity. The further weight loss of $35.42 \%$ between 380 and $500{ }^{\circ} \mathrm{C}$ should be attributed to the release of organic $\mathrm{H}_{4} \mathrm{EBDC}$ ligands (calcd: 
35.64\%). The different temperature XRD studies show the framework of compound 3 was stable to $300^{\circ} \mathrm{C}$. XRD studies indicated that the final product, upon calcinations above $500^{\circ} \mathrm{C}$, is a main phase of $\operatorname{In}_{2} \mathrm{O}_{3}$ (JCPDS: 65-3170).

Thermogravimetric analysis for compound 4 shows a weight loss of $33.20 \%$ (calcd: $33.07 \%$ ) between 35 and $350^{\circ} \mathrm{C}$, which corresponding to the loss of $\mathrm{C}_{4} \mathrm{H}_{9} \mathrm{ON}, \mathrm{CH}_{3} \mathrm{CN}$, $\mathrm{H}_{2} \mathrm{O}$, and $\left(\mathrm{CH}_{3}\right)_{2} \mathrm{NH}_{2}$ guest in the cavity. The further weight loss of $41.35 \%$ between 350 and $520{ }^{\circ} \mathrm{C}$ should be attributed to the release of organic $\mathrm{H}_{4} \mathrm{EBDC}$ ligands (calcd: 40.52\%). XRD studies indicated that the final product, upon calcinations above $500^{\circ} \mathrm{C}$, is a main phase of $\operatorname{In}_{2} \mathrm{O}_{3}$ (JCPDS: $\left.65-3170\right)$.

\section{Gas Adsorption Properties.}

The total solvent-accessible volumes for $\mathbf{1}, \mathbf{2}, \mathbf{3}$, and $\mathbf{4}$ were estimated to be $\sim 73.1 \%$, $\sim 72.5 \%, \sim 64.7 \%$, and $\sim 67.1 \%$, respectively, by summing voxels more than $1.2 \AA$ away from the framework using PLATON software. Though compounds $\mathbf{1}$ and $\mathbf{2}$ have large solvent-accessible volumes in theory, neither of them have any adsorption for $\mathrm{N}_{2}$ at low temperature, which should be due to the framework collapsed after removing the solvents in the pores. In contrast to compounds $\mathbf{1}$ and $\mathbf{2}$, it is worth noting that both compounds $\mathbf{3}$ and $\mathbf{4}$ could maintain their crystallinity upon heating temperature up to $300^{\circ} \mathrm{C}$ after full removal of solvent guest molecules (Fig. S2). The Argon adsorption/desorption studies of $\mathbf{3}$ and $\mathbf{4}$ revealed that both have reversible type I isotherms (Fig. 5), indicating that they are microporous. The Langmuir and BET surface area for 3 were estimated to be 1548 and $1285 \mathrm{~m}^{2} / \mathrm{g}$. The calculated pore 
volume was estimated to be $0.53 \mathrm{~cm}^{3} / \mathrm{g}$. The Langmuir and BET surface area, and free pore volume for 4 , estimated at $1355,1129 \mathrm{~m}^{2} / \mathrm{g}$ and $0.49 \mathrm{~cm}^{3} \mathrm{~g}^{-1}$. The surface area of 4 is higher than most of known anionic In-MOFs $\left(190-1441 \mathrm{~m}^{2} / \mathrm{g}\right){ }^{51,53-55}$

Due to the charge reversal framework features of $\mathbf{3}$ and $\mathbf{4}$ (3 adopts an overall cationic framework, while $\mathbf{4}$ has an anionic framework), it is interesting to evaluate the impact of the pore size, shape and the charge on the uptake and sorption energetics of $\mathrm{H}_{2}$ and $\mathrm{CO}_{2}$ gases. 3 and 4 exhibit significant uptake capacity for $\mathrm{CO}_{2}$ and $\mathrm{H}_{2}$. The $\mathrm{CO}_{2}$ uptake at $273 \mathrm{~K}$ and 1 atm for 3 and 4 are $91.0 \mathrm{~cm}^{3} / \mathrm{g}$ and $82.5 \mathrm{~cm}^{3} / \mathrm{g}$, respectively (Fig. 6). Although abundant MOF structures have been reported, MOFs with $\mathrm{CO}_{2}$ uptake $>90 \mathrm{~cm}^{3} / \mathrm{g}$ at $273 \mathrm{~K}$ and 1 atm are still rare. ${ }^{56}$ In the case of $\mathrm{H}_{2}, 3$ and 4 revealed a storage capacity of $1.84 \mathrm{wt} \%$ and $1.45 \mathrm{wt} \%$ at $77 \mathrm{~K}$ and 1 atm, respectively (Fig. 7). The Qst for $\mathrm{CO}_{2}$ was found to be higher in the entire studied range for 4 with a more pronounced difference at low loading, $35.2 \mathrm{~kJ} \mathrm{~mol}^{-1}$ vs. 29.7 $\mathrm{kJ} \mathrm{mol}^{-1}$ for 3 (Fig. 8a).

Since the isosteric heats of $\mathrm{CO}_{2}$ adsorption (Qst) represents the strength of the interactions between $\mathrm{CO}_{2}$ molecules and the framework lattice, there are two different inorganic MBBs in compound 4, which would provide more open metal sites, besides that, some Lewis basic amines also occupied in the pores, compound $\mathbf{4}$ has smaller pores but the pores are large enough for adsorption $\mathrm{CO}_{2}$, all these might result stronger interactions between the framework and adsorbed $\mathrm{CO}_{2}$, and then resulted higher Qst for compound 4 compared to 3.

And for $\mathrm{H}_{2}$, the isosteric heat of adsorption (Qst) of $\mathbf{4}$ was also found to be higher than 
3 (7.2 vs. $6.7 \mathrm{~kJ} \mathrm{~mol}^{-1}$ at low loading) (Fig. 8b). These observed improvements on the $\mathrm{H}_{2}$ and $\mathrm{CO}_{2}$ sorption energetics in the case of $\mathbf{4}$ is likely attributed to the narrow pore size and charge effect. $\mathrm{CO}_{2}, \mathrm{~N}_{2}$ and $\mathrm{CH}_{4}$ adsorption isotherms for compounds 3 and $\mathbf{4}$ have been also measured. As shown in Fig. 9, both compounds 3 (a) and 4 (b) exhibit a higher affinity and capacity for $\mathrm{CO}_{2}$ than for other gases. The $\mathrm{CO}_{2}$ uptake at 8000 mbar and $298 \mathrm{~K}$ for compounds $\mathbf{3}$ and $\mathbf{4}$ are 6.92 and $8.41 \mathrm{mmol} \mathrm{g}^{-1}$, respectively, and very little $\mathrm{N}_{2}$ uptake capacity (1.25 and $1.02 \mathrm{mmol} \mathrm{g}^{-1}$, respectively). On the basis of $\mathrm{CO}_{2}, \mathrm{CH}_{4}$ and $\mathrm{N}_{2}$ adsorption isotherms measured at $298 \mathrm{~K}$, initial slopes of adsorption isotherms were estimated and then used to estimate the $\mathrm{CO}_{2} / \mathrm{CH}_{4}$ and $\mathrm{CO}_{2} / \mathrm{N}_{2}$ selectivities (as ratios of the initial slopes) (Fig. 9). As a result, the $\mathrm{CO}_{2} / \mathrm{N}_{2}$ selectivity of compounds 3 and 4 are 17:1 and 21:1, respectively. The $\mathrm{CO}_{2} / \mathrm{CH}_{4}$ selectivity are 4:1 and 6:1 respectively. To our knowledge, the $\mathrm{CO}_{2} / \mathrm{N}_{2}$ and $\mathrm{CO}_{2} / \mathrm{CH}_{4}$ selectivities are comparable to ZIF-68 and porous carbon monolith. ${ }^{57,58}$

\section{Conclusions}

In summary, four indium-organic frameworks have been successfully synthesized by simple changing the solvent under the similar synthetic conditions. These materials exhibit rich structural chemistry and topologies. Both compounds $\mathbf{3}$ and $\mathbf{4}$ exhibit significant uptake capacity for $\mathrm{CO}_{2}$ and $\mathrm{H}_{2}$, and compound 4 displays improved sorption energetics due to its narrow pore size and charge effect compared to 3 . The ability to generate different building units (indium monomer, trimer, combination of monomer and trimer) in situ, by controlling the solvent system, presents a fruitful 
route for the design of novel porous MOF materials with different topologies and ionic frameworks.

\begin{abstract}
ASSOCIATED CONTENT
Supporting Information Available

Crystallographic data in CIF format, Powder XRD patterns, IR spectra, and TG curves, as well as some structure views of the compounds. This information is available free of charge via the Internet at http://pubs.acs.org/.
\end{abstract}

\title{
AUTHOR INFORMATION
}

Corresponding Author

E-mail: yunling@jlu.edu.cn; Fax: +86-431-85168624.

Notes

The authors declare no competing financial interest.

\section{ACKNOWLEDGMENTS}

This work was supported by grants from the National Natural Science Foundation of China (Nos. 21371067 and 21373095) and the Open Project of Key Laboratory of Polyoxometalate Science of Ministry of Education (130026513).

\section{References}

1. Du, R.; Zhang, N.; Xu, H.; Mao, N. N.; Duan, W. J.; Wang, J. Y.; Zhao, Q. C.; Liu, Z. F.; Zhang, J., Adv. Mater. 2014, 26 (47), 8053-8058.

2. Di Biase, E.; Sarkisov, L., Carbon 2013, 64, 262-280.

3. Liu, G. L.; Wang, Y. X.; Shen, C. J.; Ju, Z. F.; Yuan, D. Q., J. Mater. Chem. A. 2015, 3 (6), 3051-3058.

4. Lin, Z. J.; Lu, J.; Hong, M.; Cao, R., Chem. Soc. Rev. 2014, 43 (16), 5867-5895.

5. Han, Y.; Li, J. R.; Xie, Y.; Guo, G., Chem. Soc. Rev. 2014, 43 (16), 5952-5981.

6. Zhang, M.; Chen, Y.-P.; Bosch, M.; Gentle, T., III; Wang, K.; Feng, D.; Wang, Z. U.; Zhou, H.-C., Angew. Chem. Int. Edit. 2014, 53 (3), 815-818.

7. Furukawa, S.; Reboul, J.; Diring, S.; Sumida, K.; Kitagawa, S., Chem. Soc. Rev. 2014, 43 (16), 5700-5734.

8. McGuirk, C. M.; Katz, M. J.; Stern, C. L.; Sarjeant, A. A.; Hupp, J. T.; Farha, O. K.; Mirkin, C. A., J. 
Am. Chem. Soc. 2015, 137 (2), 919-925.

9. Zhang, Z.; Chen, Y.; He, S.; Zhang, J.; Xu, X.; Yang, Y.; Nosheen, F.; Saleem, F.; He, W.; Wang, X., Angew. Chem. Int. Edit. 2014, 53 (46), 12517-12521.

10. Zhang, T.; Lin, W., Chem. Soc. Rev. 2014, 43 (16), 5982-5993.

11. Zhang, F.; Wei, Y.; Wu, X.; Jiang, H.; Wang, W.; Li, H., J. Am. Chem. Soc. 2014, 136, 13963-13966.

12. Kurmoo, M., Chem. Soc. Rev. 2009, 38 (5), 1353-1379.

13. Zhao, J.-P.; Han, S.-D.; Jiang, X.; Xu, J.; Chang, Z.; Bu, X.-H., Chem. Commun. 2015, 51 (22), 4627-4630.

14. Allendorf, M. D.; Bauer, C. A.; Bhakta, R. K.; Houk, R. J., Chem. Soc. Rev. 2009, 38 (5), 1330-1352.

15. Wu, Z. F.; Tan, B.; Wang, J. Y.; Du, C. F.; Deng, Z. H.; Huang, X. Y., Chem.Commun. 2015, 51 (1), 157-160.

16. Yang, Q. Y.; Wu, K.; Jiang, J. J.; Hsu, C. W.; Pan, M.; Lehn, J. M.; Su, C. Y., Chem. Commun. 2014, 50 (57), 7702-7704.

17. Zhang, J.; Zheng, B.; Zhao, T.; Li, G.; Huo, Q.; Liu, Y., Cryst. Growth Des. 2014, 14 (5), 2394-2400.

18. Hu, Z.; Deibert, B. J.; Li, J., Chem. Soc. Rev. 2014, 43 (16), 5815-5840.

19. Kreno, L. E.; Leong, K.; Farha, O. K.; Allendorf, M.; Van Duyne, R. P.; Hupp, J. T., Chem. Rev. 2012, 112 (2), 1105-1125.

20. Rodenas, T.; Luz, I.; Prieto, G.; Seoane, B.; Miro, H.; Corma, A.; Kapteijn, F.; Llabres i Xamena, F. X.; Gascon, J., Nat. Mater. 2015, 14 (1), 48-55.

21. Al-Maythalony, B. A.; Shekhah, O.; Swaidan, R.; Belmabkhout, Y.; Pinnau, I.; Eddaoudi, M., J. Am. Chem. Soc. 2015, 137 (5), 1754-1757.

22. Zhang, Z.; Yao, Z.-Z.; Xiang, S.; Chen, B., Energy Environ. Sci. 2014, 7 (9), 2868-2899.

23. Ferrando-Soria, J.; Serra-Crespo, P.; de Lange, M.; Gascon, J.; Kapteijn, F.; Julve, M.; Cano, J.; Lloret, F.; Pasan, J.; Ruiz-Perez, C.; Journaux, Y.; Pardo, E., J. Am. Chem. Soc. 2012, 134 (37), 15301-15304.

24. Kang, Z.; Xue, M.; Fan, L.; Huang, L.; Guo, L.; Wei, G.; Chen, B.; Qiu, S., Energy Environ. Sci. 2014, 7, 4053-4060.

25. Li, J.-R.; Yu, J.; Lu, W.; Sun, L.-B.; Sculley, J.; Balbuena, P. B.; Zhou, H.-C., Nat. Commun. 2013, $4,1538$.

26. Ren, G.-J.; Chang, Z.; Xu, J.; Hu, Z.; Liu, Y.-Q.; Xu, Y.-L.; Bu, X.-H., Chem. Commun. 2016, 52 (10), 2079-2082.

27. Qiao, Z.; Wang, N.; Jiang, J.; Zhou, J., Chem. Commun. 2016, 52 (5), 974-977.

28. Ban, Y.; Li, Z.; Li, Y.; Peng, Y.; Jin, H.; Jiao, W.; Guo, A.; Wang, P.; Yang, Q.; Zhong, C.; Yang, W., Angew. Chem. Int. Edit. 2015, 54 (51), 15483-15487.

29. Wang, B.; Huang, H.; Lv, X.-L.; Xie, Y.; Li, M.; Li, J.-R., Inorg. Chem. 2014, 53 (17), 9254-9259.

30. Deng, H.; Grunder, S.; Cordova, K. E.; Valente, C.; Furukawa, H.; Hmadeh, M.; Gandara, F.; Whalley, A. C.; Liu, Z.; Asahina, S.; Kazumori, H.; O'Keeffe, M.; Terasaki, O.; Stoddart, J. F.; Yaghi, O. M., Science 2012, 336 (6084), 1018-1023.

31. Eddaoudi, M.; Kim, J.; Rosi, N.; Vodak, D.; Wachter, J.; O'Keeffe, M.; Yaghi, O. M., Science 2002, 295 (5554), 469-472.

32. Lin, X.; Telepeni, I.; Blake, A. J.; Dailly, A.; Brown, C. M.; Simmons, J. M.; Zoppi, M.; Walker, G. 
S.; Thomas, K. M.; Mays, T. J.; Hubberstey, P.; Champness, N. R.; Schroeder, M., J. Am. Chem. Soc. 2009, 131 (6), 2159-2171.

33. Suh, M. P.; Park, H. J.; Prasad, T. K.; Lim, D. W., Chem. Rev. 2012, 112 (2), 782-835.

34. Liu, J.; Thallapally, P. K.; McGrail, B. P.; Brown, D. R.; Liu, J., Chem. Soc. Rev. 2012, 41 (6), 2308-2322.

35. Dinca, M.; Long, J. R., Angew. Chem. Int. Edit. 2008, 47 (36), 6766-6779.

36. Lee, K.; Howe, J. D.; Lin, L.-C.; Smit, B.; Neaton, J. B., Chem. Mater. 2015, 27 (3), 668-678.

37. Xiong, Y.; Fan, Y.-Z.; Yang, R.; Chen, S.; Pan, M.; Jiang, J.-J.; Su, C.-Y., Chem. Commun. 2014, 50 (93), 14631-14634.

38. Ma, S.; Eckert, J.; Forster, P. M.; Yoon, J. W.; Hwang, Y. K.; Chang, J.-S.; Collier, C. D.; Parise, J. B.; Zhou, H.-C., J. Am. Chem. Soc. 2008, 130 (47), 15896-15902.

39. Ryan, P.; Broadbelt, L. J.; Snurr, R. Q., Chem. Commun. 2008, (35), 4132-4134.

40. Rowsell, J. L. C.; Yaghi, O. M., J. Am. Chem. Soc. 2006, 128 (4), 1304-1315.

41. Chen, S.; Zhang, J.; Wu, T.; Feng, P.; Bu, X., J. Am. Chem. Soc. 2009, 131 (44), 16027-16029.

42. Park, H. J.; Suh, M. P., Chem. Sci. 2013, 4 (2), 685-690.

43. Han, L.-L.; Hu, T.-P.; Mei, K.; Guo, Z.-M.; Yin, C.; Wang, Y.-X.; Zheng, J.; Wang, X.-P.; Sun, D., Dalton Trans. 2015, 44 (13), 6052-6061.

44. Ding, R.; Huang, C.; Lu, J.; Wang, J.; Song, C.; Wu, J.; Hou, H.; Fan, Y., Inorg. Chem. 2015, 54 (4), 1405-1413.

45. Qin, T.; Gong, J.; Ma, J.; Wang, X.; Wang, Y.; Xu, Y.; Shen, X.; Zhu, D., Chem. Commun. 2014, 50 (100), 15886-15889.

46. Zhang, Z.; Zaworotko, M. J., Chem. Soc. Rev. 2014, 43 (16), 5444-5455.

47. Santra, A.; Bharadwaj, P. K., Cryst. Growth Des. 2014, 14 (3), 1476-1485.

48. Majano, G.; Martin, O.; Hammes, M.; Smeets, S.; Baerlocher, C.; Perez-Ramirez, J., Adv. Funct. Mater. 2014, 24 (25), 3855-3865.

49. Zhou, H.; Dang, H.; Yi, J.-H.; Nanci, A.; Rochefort, A.; Wuest, J. D., J. Am. Chem. Soc. 2007, 129 (45), 13774-13775.

50. Liu, Y.; Eubank, J. F.; Cairns, A. J.; Eckert, J.; Kravtsov, V. C.; Luebke, R.; Eddaoudi, M., Angew. Chem. Int. Edit. 2007, 46 (18), 3278-3283.

51. Zheng, S.-T.; Bu, J. T.; Li, Y.; Wu, T.; Zuo, F.; Feng, P.; Bu, X., J. Am. Chem. Soc. 2010, 132 (48), 17062-17064.

52. Li, M.; Li, D.; O'Keeffe, M.; Yaghi, O. M., Chem. Rev. 2014, 114 (2), 1343-1370.

53. Gu, J.-M.; Kim, S.-J.; Kim, Y.; Huh, S., Crystengcomm 2012, 14 (5), 1819-1824.

54. Bosch, M.; Zhang, M.; Feng, D.; Yuan, S.; Wang, X.; Chen, Y.-P.; Zhou, H.-C., Apl Mater. 2014, 2 (12). 124103.

55. Zheng, S.-T.; Bu, J. J.; Wu, T.; Chou, C.; Feng, P.; Bu, X., Angew. Chem. Int. Edit. 2011, 50 (38), 8858-8862.

56. Chaemchuen, S.; Kabir, N. A.; Zhou, K.; Verpoort, F., Chem. Soc. Rev. 2013, 42 (24), 9304-9332.

57. Hao, G. P.; Li, W. C.; Qian, D.; Wang, G. H.; Zhang, W. P.; Zhang, T.; Wang, A. Q.; Schuth, F.; Bongard, H. J.; Lu, A. H., J. Am. Chem. Soc. 2011, 133 (29), 11378-11388.

58. Banerjee, R.; Furukawa, H.; Britt, D.; Knobler, C.; O'Keeffe, M.; Yaghi, O. M., J. Am. Chem. Soc. 2009, 131 (11), 3875-3877. 


\section{Caption of Figures:}

Scheme 1. Four indium-organic frameworks have been synthesized by changing the solvent under similar synthetic conditions.

Figure 1. A description of the structure of 1: (a) each $\operatorname{~In}^{3+}$ centre is eight-coordinated to oxygen atoms of four carboxylate groups from four $\mathrm{EBDC}^{4-}$ ligands, each ligand binds to four separate $\mathrm{In}^{3+}$ centres, the inorganic $\left(\left[\operatorname{In}\left(\mathrm{O}_{2} \mathrm{C}\right)_{4}\right]^{-}\right)$node and organic $\left(\mathrm{EBDC}^{4-}\right)$ node are rationalized as having tetrahedral and square-planar geometry, respectively, these two types of nodes alternately connected to form pts topology framework; (b) and c) Space-filling views for 1 showing the channels along [010] and [001] directions, respectively; (d) Ball-and-stick representation of 1 with the indium tetrahedral node shown in green and the square planar EBDC node shown in red; (e) Natural tiling representation of $\mathbf{1}$. Color code: In, green; C, gray; O, red.

Figure 2. A description of the structure of 2: (a) the inorganic $\left(\left[\operatorname{In}\left(\mathrm{O}_{2} \mathrm{C}\right)_{4}\right]^{-}\right)$node and organic $\left(\mathrm{EBDC}^{4-}\right)$ node are rationalized as having tetrahedral and square-planar geometry, respectively, the two types of nodes alternately connected to form a new type of topology framework; (b) and (c) Space-filling representations of the framework of compound 2 showing the channels along [001] and [110] directions, respectively; (d) Ball-and-stick representation of $\mathbf{2}$ with the indium tetrahedral node shown in green and the square planar EBDC node shown in red; (e) Natural tiling representation of $\mathbf{2}$. Color code: In, green; $\mathrm{C}$, gray; $\mathrm{O}$, red.

Figure 3. A description of the structure of 3: (a) the inorganic indium trimer node $\left[\mathrm{In}_{3} \mathrm{O}\left(\mathrm{O}_{2} \mathrm{C}\right)_{6}\left(\mathrm{H}_{2} \mathrm{O}\right)_{3}\right]^{+}$and organic $\left(\mathrm{EBDC}^{4-}\right)$ node are rationalized as having pseudo-octahedron and square-planar geometry, respectively, the two nodes 
alternately connected to result in the formation of an edge-transitive 3-periodic network with soc topology; (b) Space-filling representations of the framework of compound 3 showing the channels along [100] direction; (c) Schematic and Ball-and-stick representations of $\mathbf{3}$ with soc topology; (d) Natural tiling representation of soc net.

Figure 4. A description of the structure of 4: (a) the inorganic monomeric $\left[\operatorname{In}\left(\mathrm{O}_{2} \mathrm{C}\right)_{4}\right]^{-}$ node and the trimeric $\left[\operatorname{In}_{3} \mathrm{O}\left(\mathrm{O}_{2} \mathrm{C}\right)_{6}\left(\mathrm{H}_{2} \mathrm{O}\right)_{3}\right]^{+}$node can be rationalized as tetrahedral and pseudo-octahedron geometry, respectively, the organic $\left(\mathrm{EBDC}^{4-}\right)$ is still rationalized as square-planar geometry, each EBDC ligand is linked by two monomeric $\operatorname{In}^{3+}$ nodes and two trimeric nodes in a cis configuration to generate a novel topological network; (b), (c) and (d) Space-filling representations of the framework of compound 4 showing the channels along [100], [110] and [111] directions, respectively; (e) Ball-and-stick representation of $\mathbf{4}$ with the indium tetrahedral nodes shown in green, indium trigonal prism nodes shown in green, and the square planar $\mathrm{EBDC}^{4-}$ nodes shown in red; (f) Natural tiling representation of 4.

Figure 5. Argon gas sorption isotherms and pore size distribution analysis for compounds 3 ( $\mathrm{a}$ and $\mathrm{b}$ ) and 4 (c and $\mathrm{d}$ ) by using the cylindrical NLDFT model.

Figure 6. $\mathrm{CO}_{2}$ adsorption isotherms of compounds 3 (a) and 4 (b)

Figure 7. $\mathrm{H}_{2}$ adsorption isotherms of compounds 3 (a) and 4 (b)

Figure 8. Variation of the thermodynamic parameters of isosteric heat of adsorption (Qst) for $\mathrm{CO}_{2}$ and $\mathrm{H}_{2}$ uptakes in compounds 3 (a) and 4 (b).

Figure 9. $\mathrm{CO}_{2}, \mathrm{~N}_{2}$ and $\mathrm{CH}_{4}$ adsorption isotherms for compound $\mathbf{3}$ (a) and compound 4 
(b) at $298 \mathrm{~K}$; Initial slope calculation for $\mathrm{CO}_{2}, \mathrm{~N}_{2}$ and $\mathrm{CH}_{4}$ isotherms collected at $298 \mathrm{~K}$

for compound 3 (c) and compound 4 (d). $\left(\mathrm{CO}_{2}\right.$ : red squares; $\mathrm{CH}_{4}$ : green circles; $\mathrm{N}_{2}$ :

blue triangles). 
Table 1. Crystal data and structure refinement for compounds 1-4.

\begin{tabular}{|c|c|c|c|c|}
\hline & 1 & 2 & 3 & 4 \\
\hline empirical formula & $\mathrm{C}_{30} \mathrm{H}_{42} \mathrm{InN}_{3} \mathrm{O}_{13} \mathrm{~S}_{2}$ & $\mathrm{C}_{23} \mathrm{H}_{21} \mathrm{InN}_{2} \mathrm{O}_{9}$ & $\mathrm{C}_{40} \mathrm{H}_{43.50} \mathrm{In}_{3} \mathrm{~N}_{6} \mathrm{O}_{22.75}$ & $\mathrm{C}_{108} \mathrm{H}_{36} \mathrm{In}_{9} \mathrm{O}_{56}$ \\
\hline formula weight & 831.61 & 584.24 & 1316.77 & 3262.75 \\
\hline temperature $(\mathrm{K})$ & $296(2)$ & $293(2)$ & 293(2) & $296(2)$ \\
\hline wavelength $(\AA)$ & 0.71073 & 0.71073 & 0.71073 & 0.71073 \\
\hline crystal system & Tetragonal & Orthorhombic & Cubic & Hexagonal \\
\hline space group & $\mathrm{P} 4_{2} / \mathrm{mmc}$ & Pbam & $\mathrm{Pm}-3 \mathrm{n}$ & $\mathrm{R} 3_{2}$ \\
\hline$a(\AA)$ & $9.9798(2)$ & $25.161(5)$ & $22.6230(4)$ & $22.1811(12)$ \\
\hline$b(\AA)$ & $9.9798(2)$ & $35.988(7)$ & $22.6230(4)$ & $22.1811(12)$ \\
\hline$c(\AA)$ & $23.1921(8)$ & $10.021(2)$ & $22.6230(4)$ & $41.961(5)$ \\
\hline$\alpha(\operatorname{deg})$ & 90 & 90 & 90 & 90 \\
\hline$\beta(\operatorname{deg})$ & 90 & 90 & 90 & 90 \\
\hline$\gamma(\operatorname{deg})$ & 90 & 90 & 90 & 120 \\
\hline$V\left(\AA^{3}\right)$ & $2309.85(10)$ & $9074(3)$ & $11578.5(4)$ & $17879(3)$ \\
\hline$Z$ & 2 & 8 & 8 & 3 \\
\hline$D_{\text {calc }}\left(\mathrm{g} / \mathrm{cm}^{3}\right)$ & 1.196 & 0.855 & 1.511 & 0.909 \\
\hline$\mu\left(\mathrm{mm}^{-1}\right)$ & 0.653 & 0.550 & 1.260 & 0.902 \\
\hline$F(000)$ & 856 & 2352 & 5236 & 4719 \\
\hline$\theta$ range (deg) & $1.76-25$ & $1.62-28.38$ & $1.80-25.68$ & $1.17-28.30$ \\
\hline Reflections collected & 12713 & 65514 & 64666 & 43519 \\
\hline Reflections unique $\left(R_{\text {int }}\right)$ & $1182(0.0288)$ & $11948(0.0824)$ & $1935(0.1768)$ & $9788(0.1132)$ \\
\hline Goodness-of-fit on $F^{2}$ & 1.371 & 1.088 & 1.074 & 0.956 \\
\hline $\mathrm{R}_{1, \mathrm{w}} \mathrm{R}_{2}[I>2 \sigma(I)]$ & $0.0667,0.2629$ & $0.0879,0.2669$ & $0.0809,0.1972$ & $0.0952,0.2262$ \\
\hline $\mathrm{R}_{1}, \mathrm{wR}_{2}$ (all data) & $0.0753,0.2687$ & $0.1388,0.3065$ & $0.1454,0.2571$ & $0.1208,0.2439$ \\
\hline
\end{tabular}




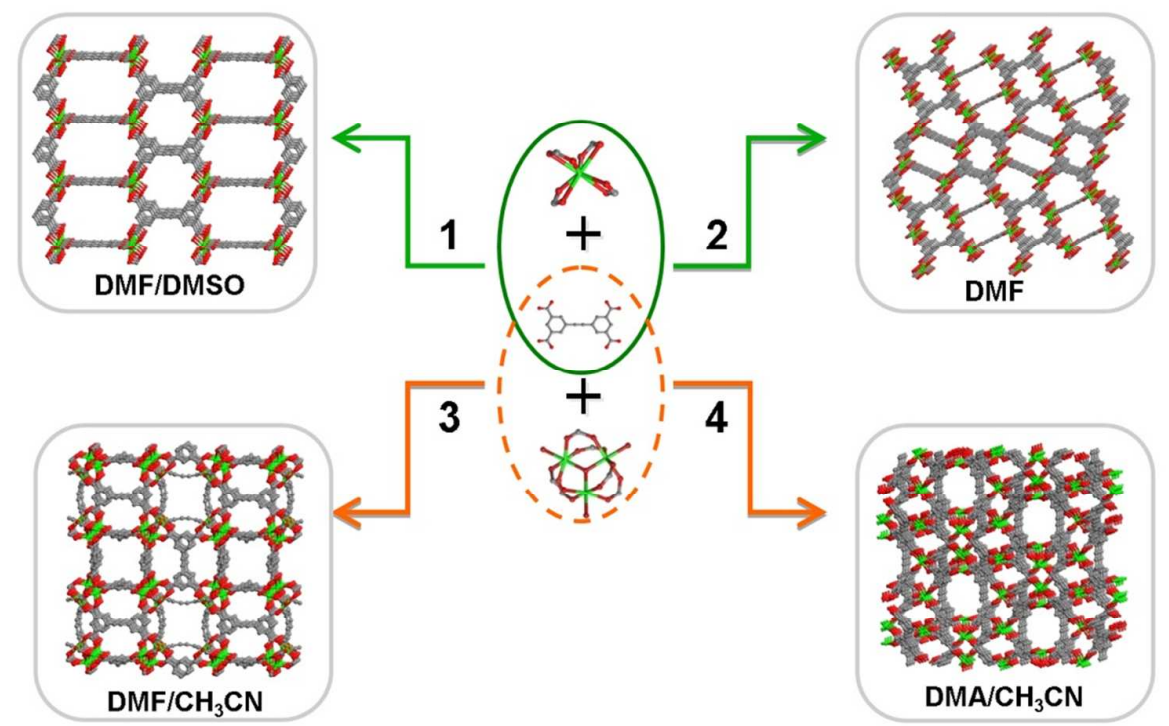

Scheme 1 
(a)

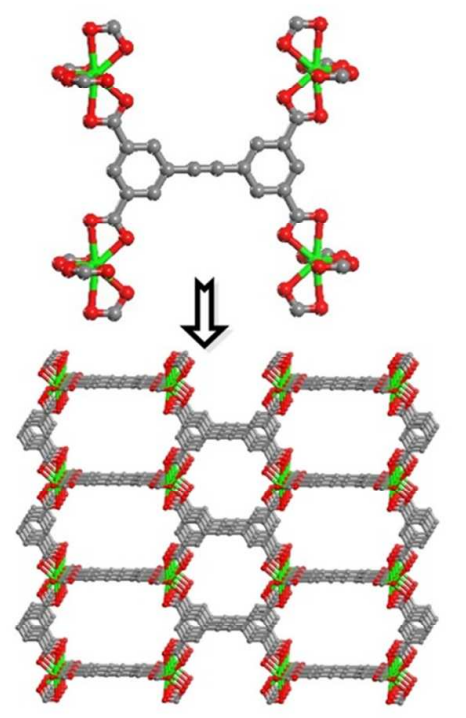

(b)

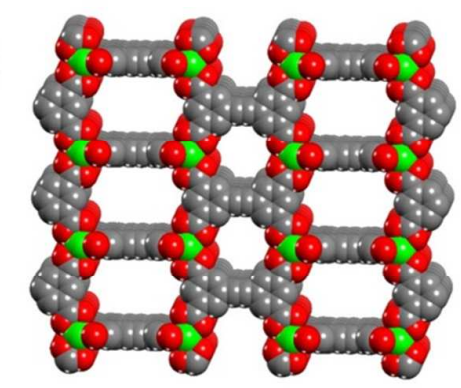

(d)

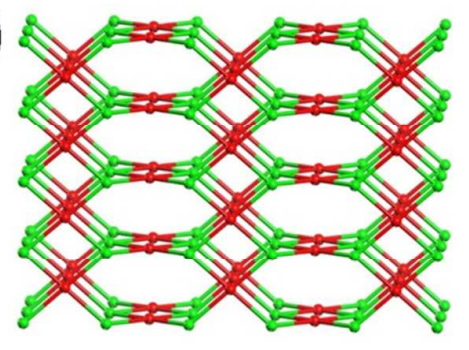

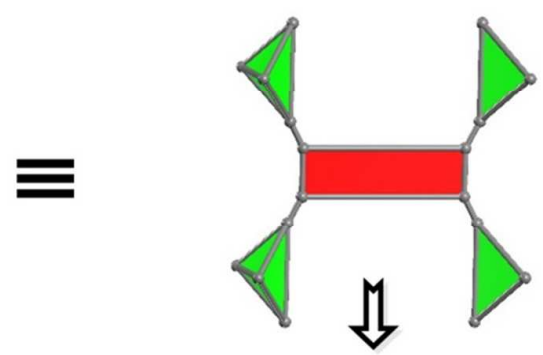

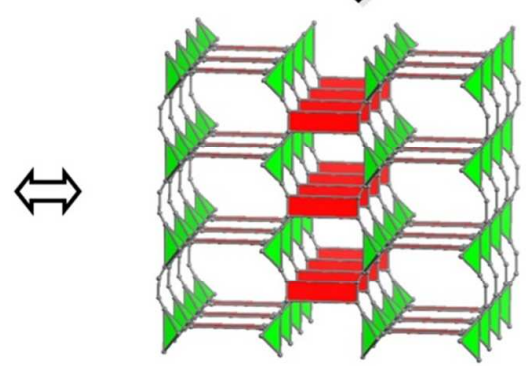

(c)

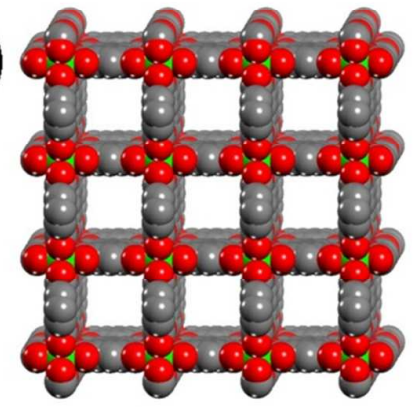

(e)

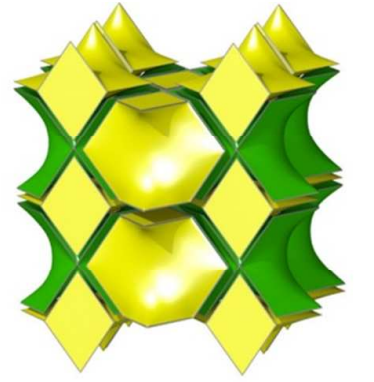

Figure 1 
(a)

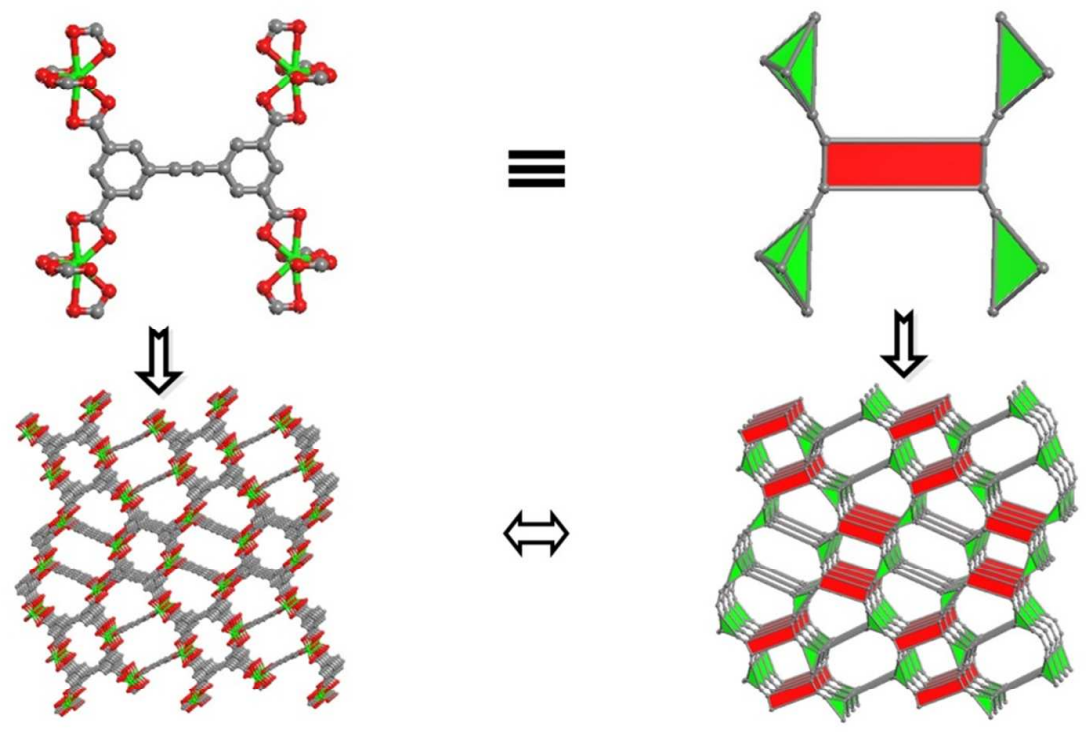

(b)

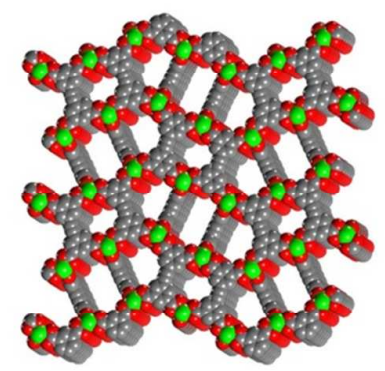

(c)

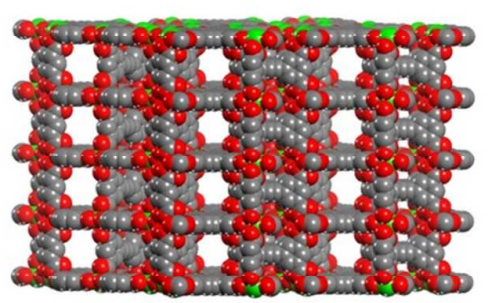

(d)

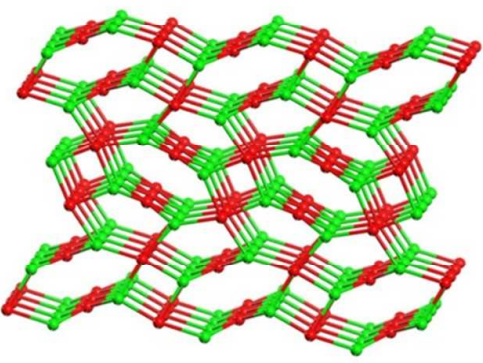

(e)

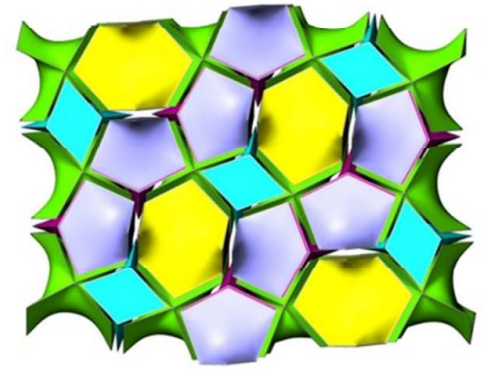

Figure 2 
(a)

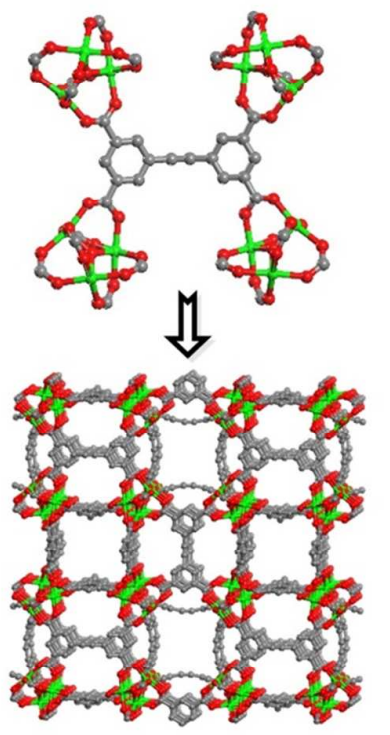

(b)

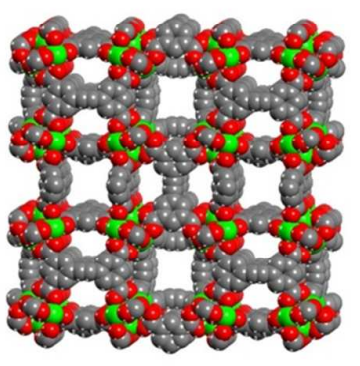

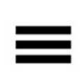

$\Leftrightarrow$

(c)

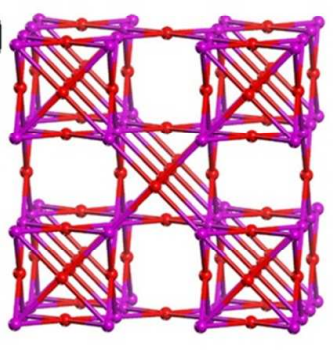

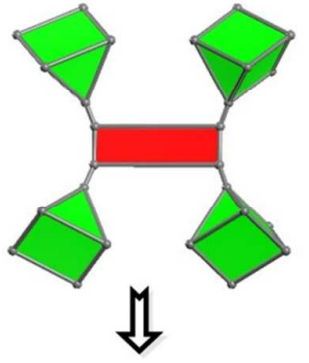

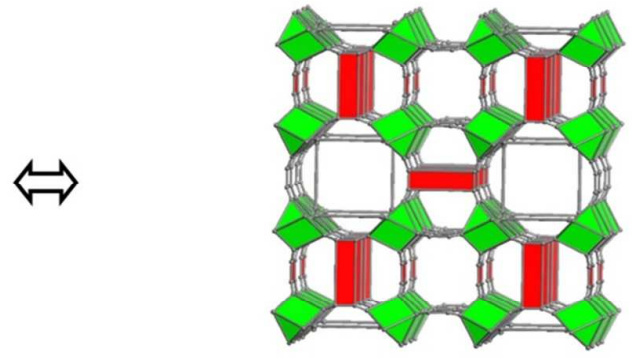

(d)

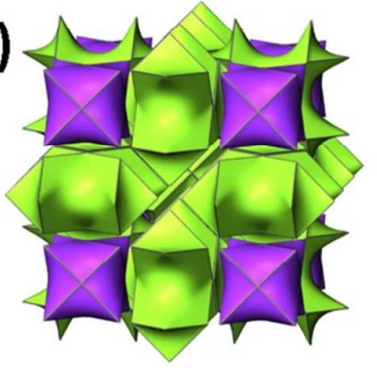

Figure 3 
(a)

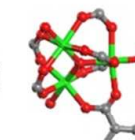

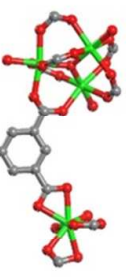
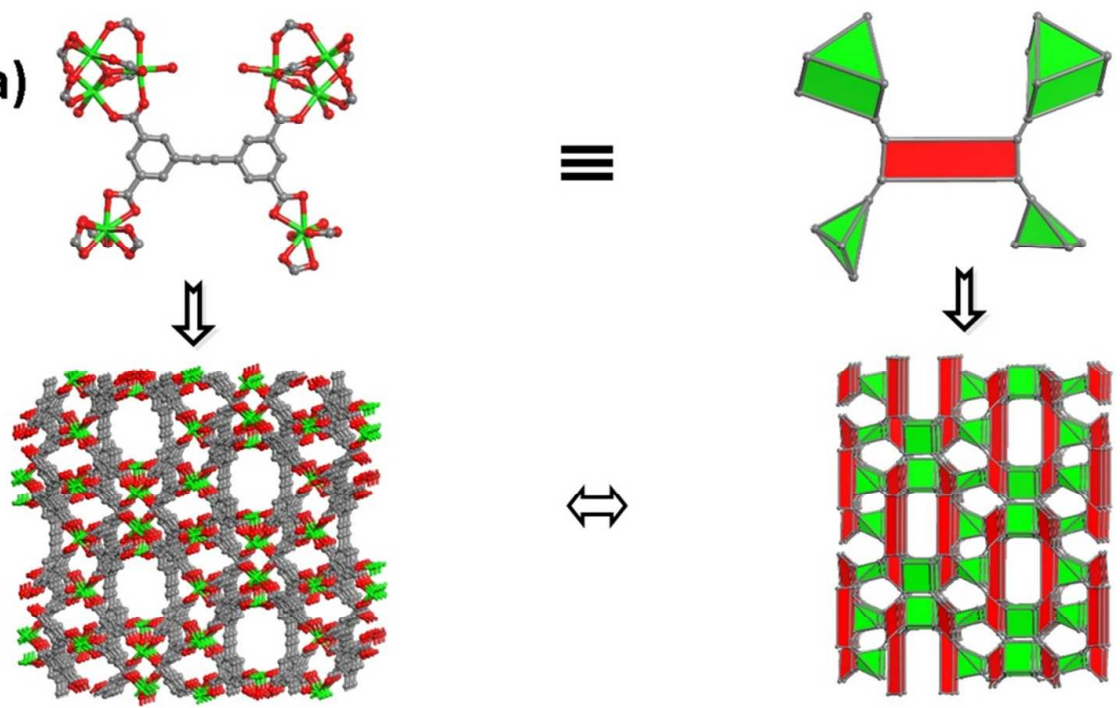

(b)

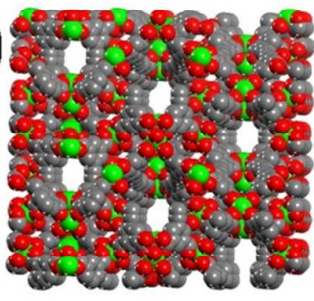

(c)
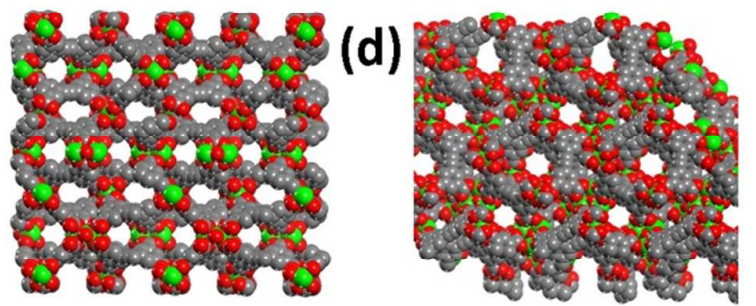

(e)

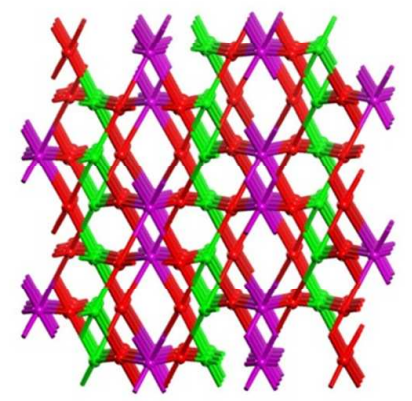

(f)

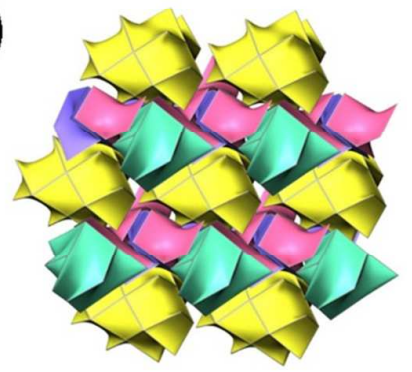

Figure 4 
(a)

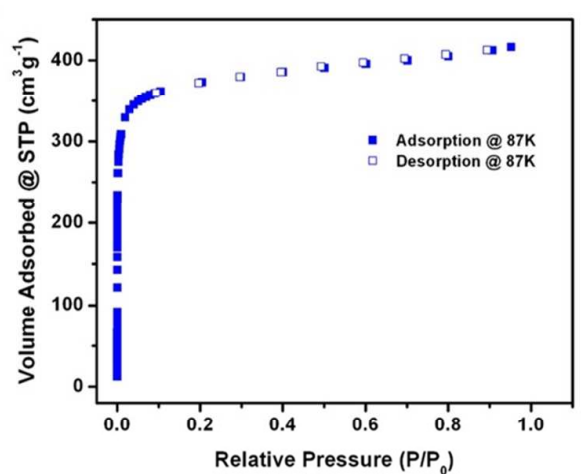

(c)

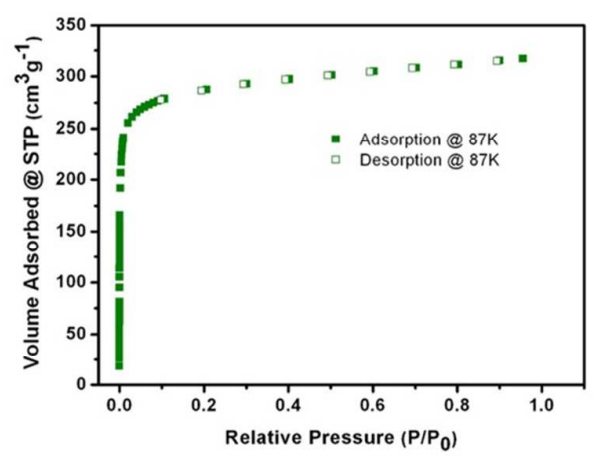

(b)

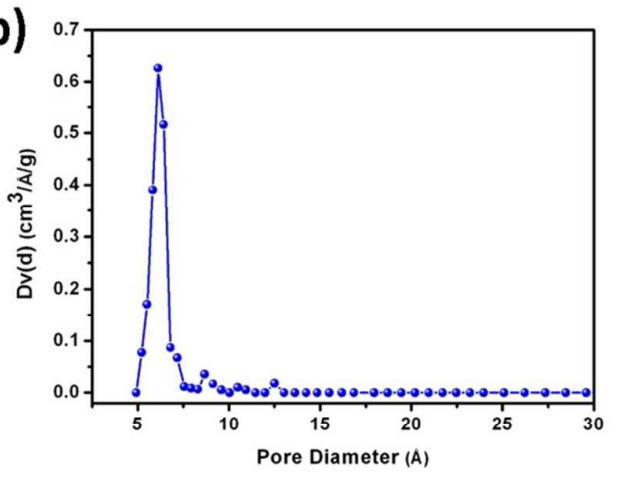

(d)

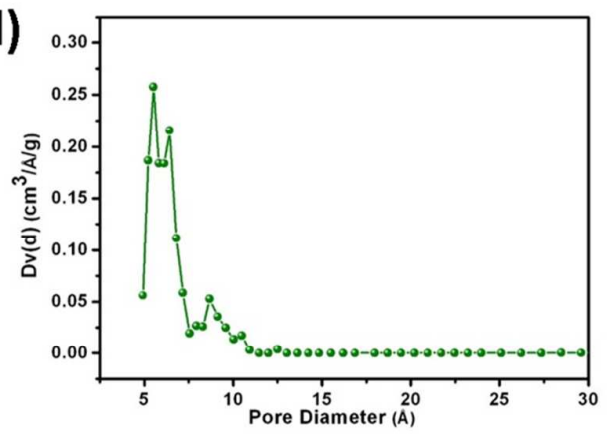

Figure 5 
(a)

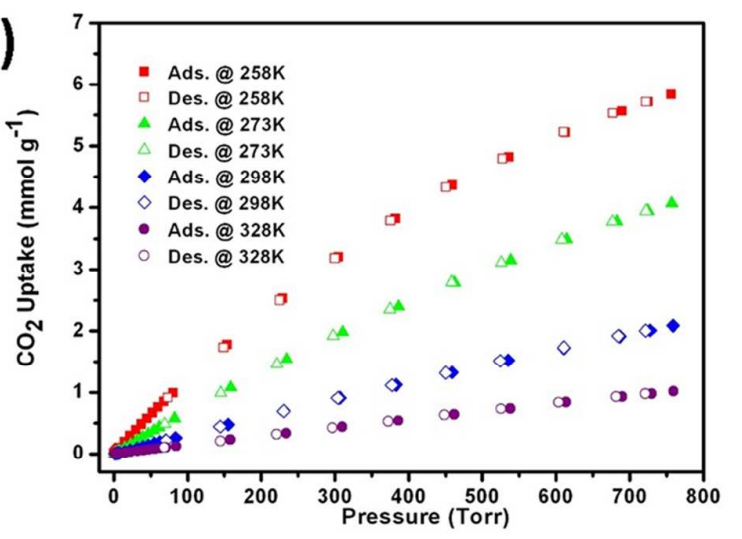

(b)

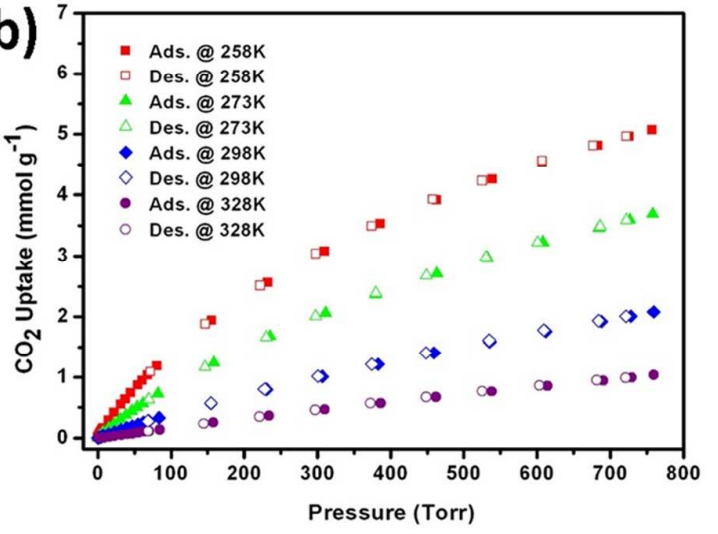

Figure 6 
1

2

3

4

5

6

7

8

9

10

11

12

13

14

15

16

17

18

19

20

21

22

23

24

25

26

27

28

29

30

31

32

33

34

35

36

37

38

39

40

41

42

43

44

45

46

47

48

49

50

51

52

53

54

55

56

57

58

59

60
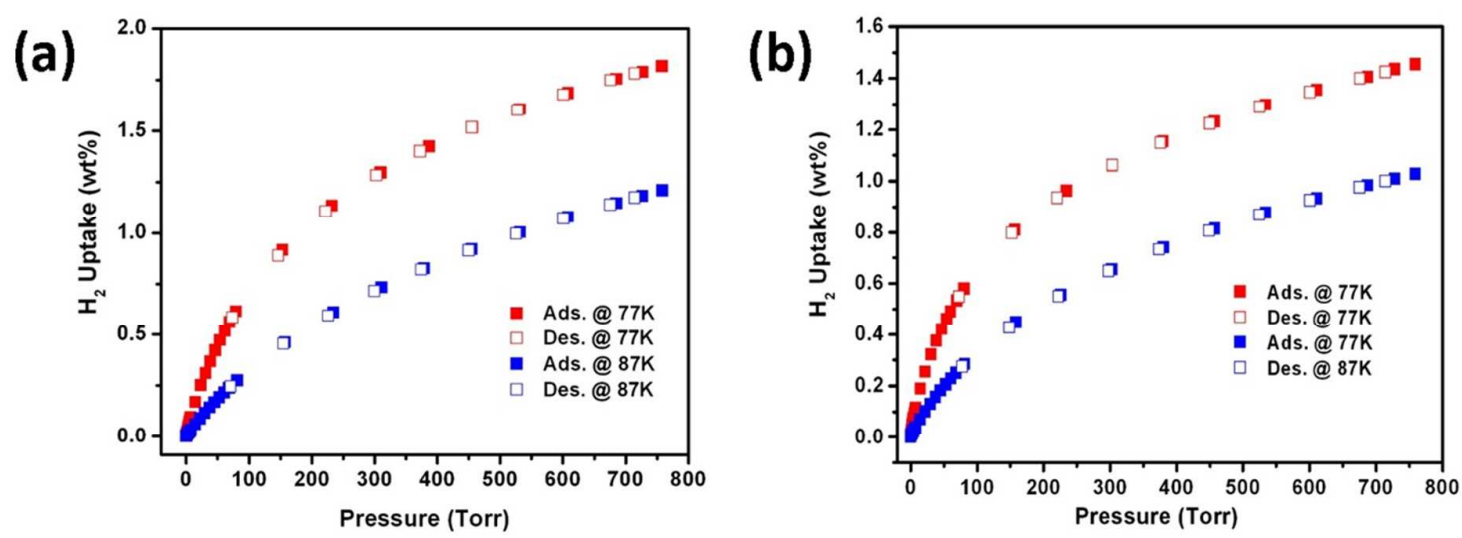

Figure 7 

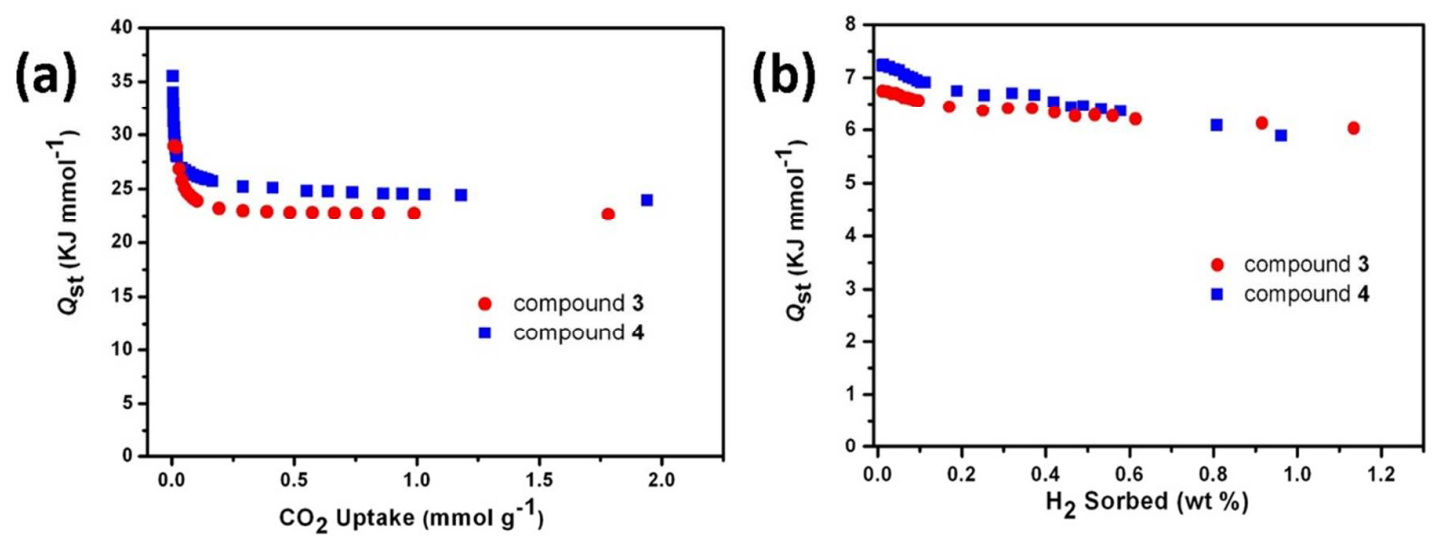

Figure 8

19

20

21

22

23

24

25

26

27

28

29

30

31

32

33

34

35

36

37

38

39

40

41

42

43

44

45

46

47

48

49

50

51

52

53

54

55

56

57

58

59 
(a)

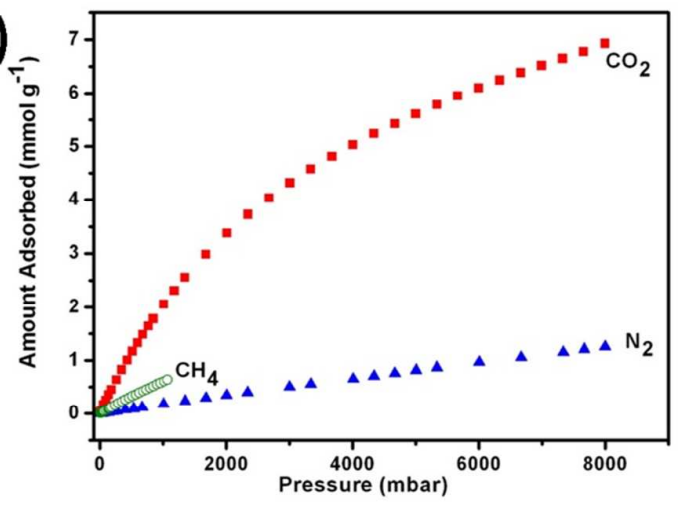

(c)

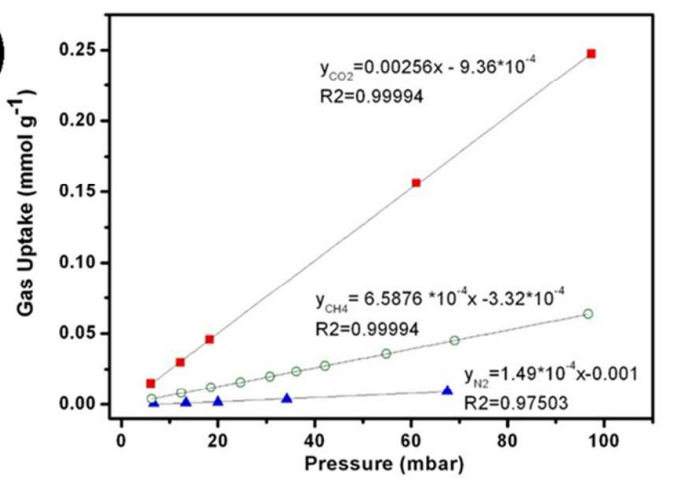

(b)

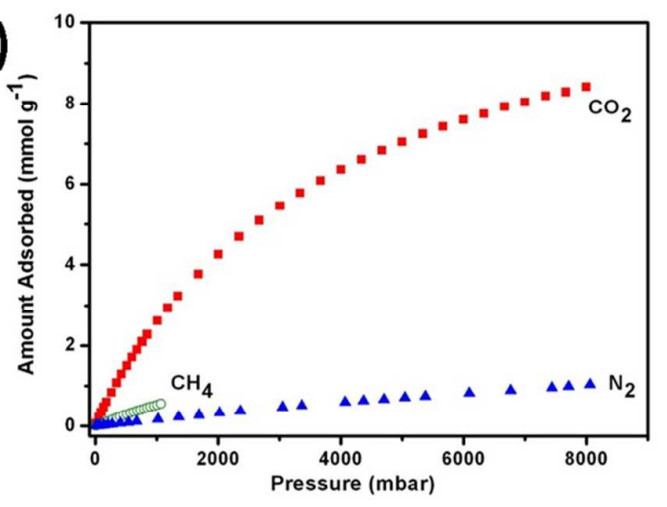

(d)

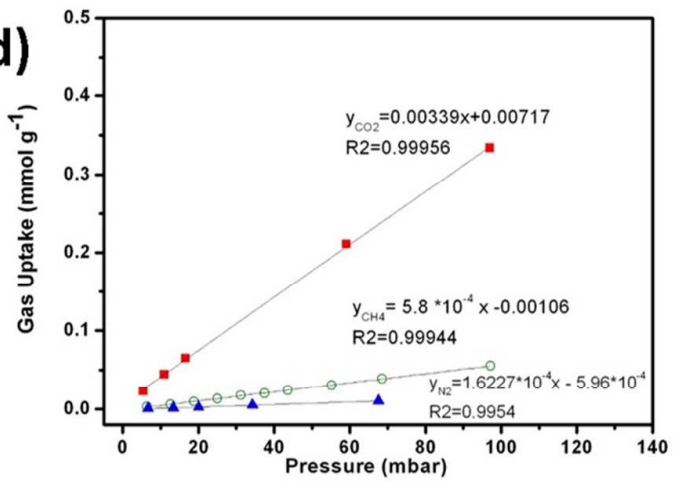

Figure 9 


\section{Table of Contents}

\section{Solvent-Controlled Assembly of ionic Metal-Organic Frameworks Based on Indium and Tetracarboxylate Ligand: Topology Variety and Gas Sorption Properties}

Bing Zheng, ${ }^{\text {a,d }}$ Xiaodong Sun, ${ }^{\mathrm{a}}$ Guanghua Li, ${ }^{\mathrm{a}}$ Amy J. Cairns, ${ }^{\mathrm{b}}$ Victor Ch. Kravtsov, ${ }^{\mathrm{c}}$ Qisheng Huo, ${ }^{a}$ Yunling Liu, ${ }^{* a}$ and Mohamed Eddaoudi ${ }^{\mathrm{b}}$

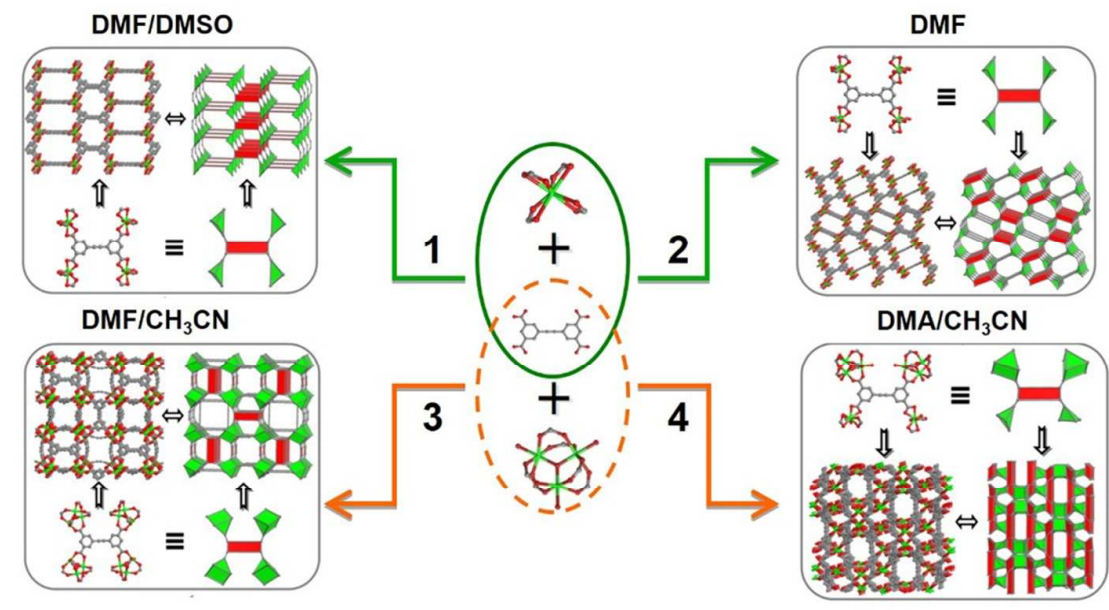

Four metal-organic frameworks (MOFs) based on indium and tetracarboxylate ligand have been synthesized through regulation of the solvent conditions, the resulted compounds are anionic or cationic frameworks with pts, soc and unprecedented topologies and exhibiting high $\mathrm{H}_{2}$ and $\mathrm{CO}_{2}$ uptake capacity. 